\title{
Idiopathic Anaphylaxis: Case Report
}

\author{
İdiyopatik Anafilâksi: Olgu Sunumu
}

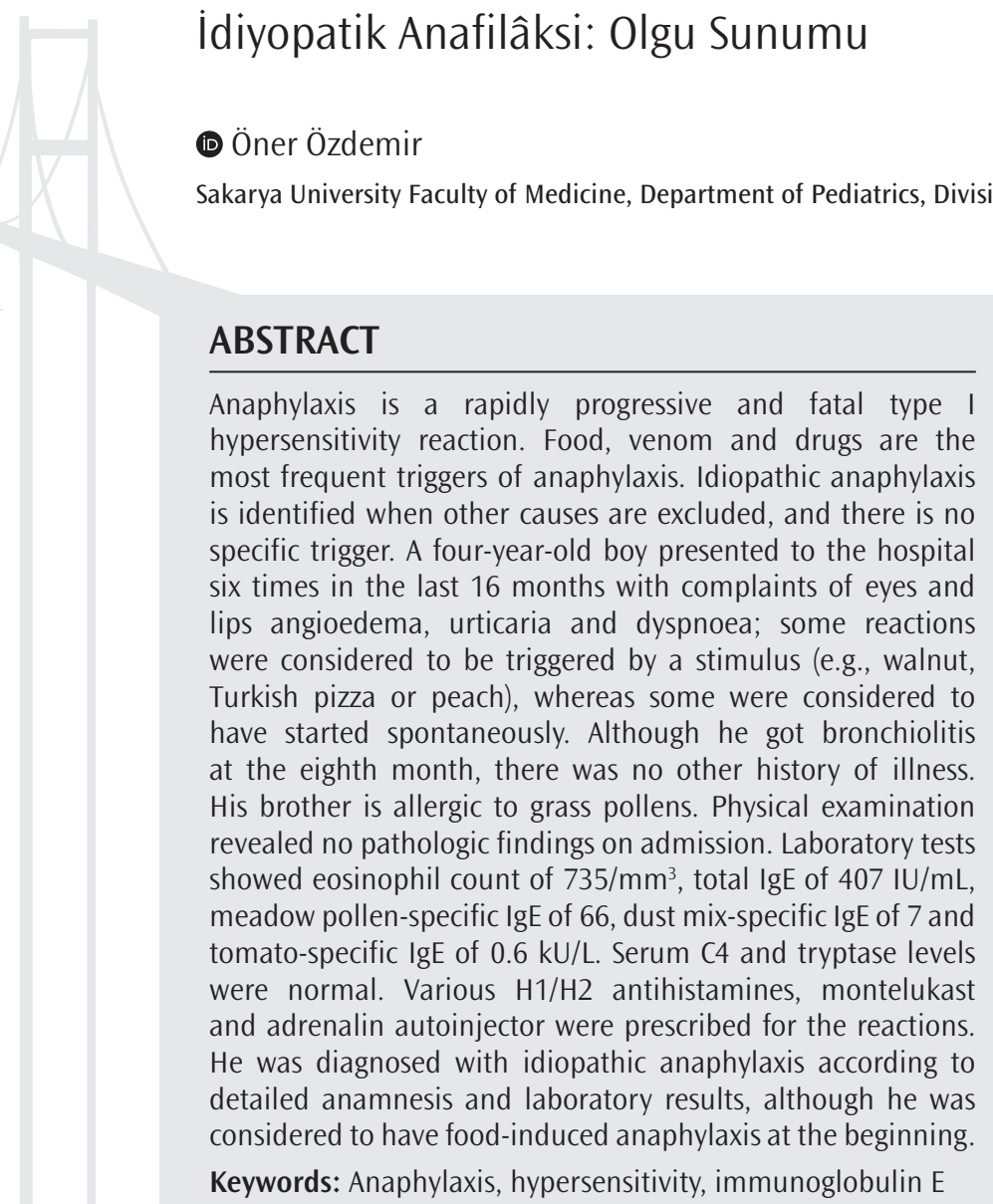

\section{ÖZ}

Anafilaksi hızlı ilerleyen ve ölümcül tip 1 alerjik aşırı duyarıı reaksiyonudur. Besin, venom ve ilaç anafilaksinin en sık karșılașılan tetikleyici faktörleridir. Diğer nedenler dışlanıp spesifik bir tetikleyici tespit edilemediğinde idiyopatik anafilaksi olarak tanımlanır. Dört yașındaki erkek hasta, 16 ay içinde 6 kez bazen uyaranla (ceviz, lahmacun, şeftali vb.) bazen de spontan olarak gerçekleșen dudak-gözlerde șișme, döküntü ve nefes darlığı şikayetleri ile hastaneye başvurmuştu. Sekiz aylıkken bir defa bronşiolit olduğu bilinen hastanın başka hastalık öyküsü yoktu. Abisinde çim polenine alerjisi olduğu öğrenildi. Yatıșında yapılan fizik muayenesinde özellik görülmedi. Laboratuvar testlerinde; eozinofil: $735 / \mathrm{mm}^{3}$, total IgE: 407 IU/mL, çayır polen karışımına spesifik IgE: 66 kU/L, toz karıșımı: 7 kU/L ve domates: 0,6 kU/L saptandı. Serum C4 ve triptaz değeri normal bulundu. Değișik H1/H2 antihistaminikler, montelukast ve ataklar için de adrenalin otoenjektör reçete edilmişti. Önce besinle tetiklenen anafilaksi gibi düşünülen hastanın, ayrıntılı anamnez ve tetkikler sonrasında idiyopatik anafilaksi tanısı konulmasından bahsedilecektir.

Anahtar Kelimeler: Anafilaksi, hipersensitivite, immünoglobulin E

\section{Introduction}

Anaphylaxis is a life threatening allergic early (type 1) hypersensitivity reaction formed by the release of bioactive mediators from mast cells and basophiles (1). Anaphylaxis can develop through an immunoglobulin E (IgE)-mediated or non-IgE-mediated mechanism. In both situations it has symptoms in systems such as; skin/mucosa (urticaria, angioedema) respiration (bronchospasm, laryngeal edema), cardiovascular (hypotension, dysrhytmia, myocardial ischemia) and gastrointestinal (nausea, colic type stomach pain, vomit, diarrhea). Anaphylaxis can be diagnosed when symptoms formed in at least two systems after the potential (suspicious or unknown cause) exposure to an allergen. Anaphylaxis is usually caused by foods, drugs, and insect stings (venom). In general the prevalence of anaphylaxis is between $2 \%-0.05 \%(1-3)$.
Idiopathic anaphylaxis is diagnosed in the presence of signs and symptoms consistent with anaphylaxis, although no specific trigger can be detected in a patient. Prevalence is approximately $1 / 10.000$. Since it is firstly known in 1978 for the adults, case series have been reported for a group of 335 child + adult subjects aged between 5-83 and a group of 22 children, however the experience is limited in Turkey $(4,5)$. Unlike being rarely seen, it is important in the clinical aspect in respect to disease and death risk. It should also be noted that today there is no proven treatment and it can be misdiagnosed with other important mast cell diseases (eg. idiopathic mast cell activation syndrome, monoclonal mast cell activation syndrome, systemic mastocytosis) $(2,3,6)$. In this report, we described a patient having anaphylaxis attacks after consumption of various food elements (eg. walnut, Turkish pizza, peach) or being 
diagnosed with idiopathic anaphylaxis from detailed anamnesis and laboratory, although he was considered as food-induced anaphylaxis at the beginning and also we mentioned our experience about this disease.

\section{Case Report}

Four-year-old male patient had been admitted to hospital 6 times with attacks in the last 16 months with itching, swelling of lips and eyes, rash, urticaria, shortness of breath stimulated (different foods: walnuts, Turkish pizza, peach) or spontaneously. In the first attack, he had applied to hospital with urticarial rash, oedema in eyelids and inmouth symptoms 10 minutes after he ate walnuts. Being diagnosed with the allergic reaction; antihistaminic and dexamethasone treatment had been applied. With the purpose of further examination and treatment, the patient is hospitalized in pediatrics service. Although he got bronchiolitis at the eighth month, there was no other history of illness. In family history, his brother was allergic to grass pollens. In the physical examination after his hospitalization, his general status was good, growth and development was normal, tension: 90/60 mmHg, cooperation and orientation were normal. Respiration, cardiovascular, gastrointestinal and neurological system examination findings were normal. After this treatment, the patient hospitalized 5 more time with attacks some were thought to be triggered by a stimulus (e.g. Turkish pizza, peach) and some were spontaneously started (unknown reason).

In the second attack, the patient had been admitted to hospital with pruritus, urticarial rash, and cough symptoms 10 minutes after he ate Turkish pizza. The patient had been given antihistamine (phenyramine) and dexamethasone again and referred to the emergency service. In pediatric emergency service, urticarial rash regressed, cough ended, vital findings were stabile and the patient was hospitalized in pediatric service on the purpose of supervision. In admission, the laboratory tests were detected as the following; eosinophil: $130-735 / \mathrm{mm}^{3}$, total IgE: 591/407 IU/mL, meadow grass pollen specific IgE: $66.3 \mathrm{kU} / \mathrm{L}$, specific IgE-HP1 dust mixture: $7.38 \mathrm{kU} / \mathrm{L}$ and specific IgE-tomato: $0.65 \mathrm{kU} / \mathrm{L}$. The other specific IgE tests (tree pollen mixtures, mold allergens, green peas, white beans, carrot, potato, peanut, walnut, brasilian nuts, almond, coconut, chocolate, cacao, wheat flour, gluten, hazelnut, strawberry, peach) results were negative. C4: $0.15 \mathrm{~g} / \mathrm{L}$, serum tryptase: $<4 \mathrm{ng} /$ $\mathrm{mL}$, latex RF: $<11.5 \mathrm{IU} / \mathrm{mL}$, c-reactive protein, antinuclear antibodies, routine biochemistry, sedimentation rate, full urine analysis and stools parasite examinations were normal (Table 1). In the skin prick test applied to the patient with an age appropriate screening panel consistent with specific IgE; histamine was $7 \times 7 \mathrm{~mm}$, dermatophagoides farinae $5 \times 7 \mathrm{~mm}$ and meadow grass $7 \times 6 \mathrm{~mm}$. Despite positive relation with aeroallergens found, there was no clinical response (allergic rhinitis or asthma) in the patient. The positive relation with tomatoes may be explained by the attack after the patient ate Turkish pizza but there was no prior information about patient's allergy to tomatoes. No common allergens found which can cause a cross reaction in between "tomatoes" and "house dust mites and meadow pollen". The patient was prescribed with $\mathrm{H}_{1}$ second generation antihistaminic (cetirizine, $2.5 \mathrm{mg} /$ day and desloratadine, $1 \mathrm{mg} /$ day) and also $0.15 \mathrm{mg}$ epinephrine auto-injector (junior) to use in case of an attack before he was discharged.

The patient was then admitted to the hospital with four attacks, sometimes suspected of stimulus (such as peaches) and sometimes spontaneous (unknown reason). Despite the third attack had started spontaneously without any trigger, the parents had not applied epinephrine auto-injector and applied to pediatric emergency service. With the following vital findings; pulse: $160 / \mathrm{min}$, respiration: 40/min, blood pressure: 80/60 mm/Hg, SPO2: 91\% the patient had been diagnosed with anaphylaxis and cured right after epinephrine treatment. The patient was prescribed with $\mathrm{H}_{1}$ (pheniramine maleate, 2 $\mathrm{mg} / \mathrm{kg} /$ day) ve $\mathrm{H}_{2}$ (ranitidin, $2 \mathrm{mg} / \mathrm{kg} /$ day) antihistaminic syrups and also epinephrine auto-injector to use in case of an attack.

Similarly, in the fourth attack which started with skin and respiratory symptoms but with no trigger, the complaints regressed after epinephrine auto-injector applied by the parents. The fifth attack had started with pruritus, urticarial rash, cough and shortness of breath symptoms 15 minutes after the patient ate peach, epinephrine autoinjector had been applied at home and when the patient applied to pediatric emergency service the symptoms had regressed. The patient was hospitalized with the purpose of supervision and discharged after 12 hours with no problems. Like the third and fourth attacks, the sixth attack happened with skin and respiratory symptoms but with no trigger, and the complaints regressed after epinephrine auto-injector applied by the parents.

Thereby the patient had 6 different attacks in 16 months. After the last attack, montelukast (4 mg/day) was also included to patient's medication plan in addition to $\mathrm{H}_{1}$ (ketotifen, $0.1 \mathrm{mg} / \mathrm{kg} /$ day) ve $\mathrm{H}_{2}$ (ranitidin, $2 \mathrm{mg} /$ $\mathrm{kg} /$ day) antihistaminic syrups. Under these triple medication, no attacks observed through more than 12 months of follow-up (Figure 1) Therewith, firstly $\mathrm{H}_{2}$ antihistaminic was removed from the medication plan. Then $\mathrm{H}_{1}$ antihistaminic was reductively removed from the medication plan but planned to continue the montelukast treatment with the continuing follow-ups. Considering the clinical profile and laboratory test results, the patient was diagnosed with Idiopathic Anaphylaxis. (An informed verbal consent was provided from the patient's parents for this report).

Table 1. Significant laboratory test results

\begin{tabular}{|l|l|}
\hline Eosinophil & $735 / \mathrm{mm}$ \\
\hline Total IgE & $591 \mathrm{IU} / \mathrm{mL}$ \\
\hline Meadow grass pollen spesific IgE & $66.3 \mathrm{kU} / \mathrm{L}$ \\
\hline House dust mite specific IgE & $7.38 \mathrm{kU} / \mathrm{L}$ \\
\hline Tomato specific IgE & $0.65 \mathrm{kU} / \mathrm{L}$ \\
\hline Other specific IgE & Negative \\
\hline C4 level & $0.15 \mathrm{~g} / \mathrm{L}$ \\
\hline Tryptase & $<4 \mathrm{ng} / \mathrm{mL}$ \\
\hline RF & $<11.5 \mathrm{IU} / \mathrm{mL}$ \\
\hline ANA & Negative \\
\hline CRP & $<3.02$ \\
\hline
\end{tabular}

IgE: immunoglobulin E, RF: rheumatoid factor, ANA: antinuclear antibodies, CRP c-reactive protein 


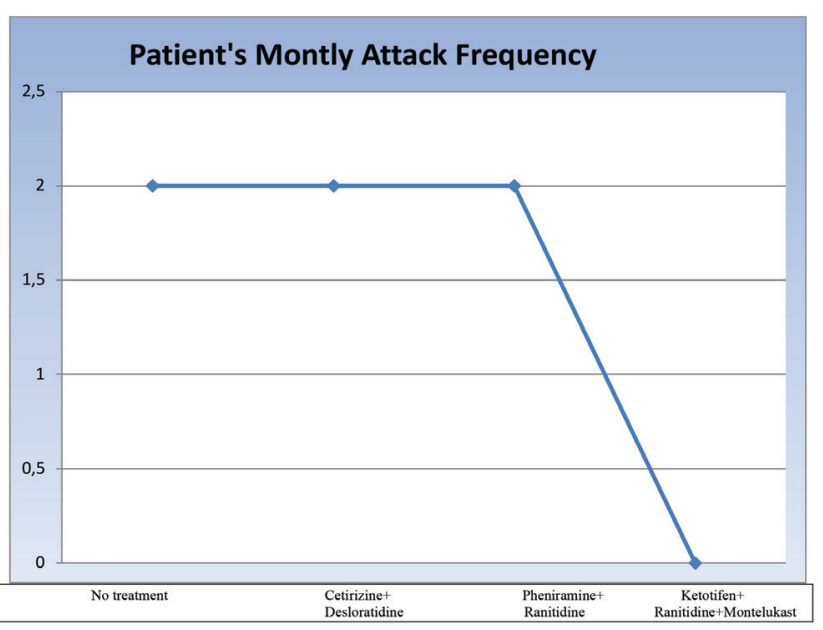

Figure 1. Decreasing attack numbers of the patient with idiopathic anaphylaxis, before and after the treatment

\section{Discussion}

Anaphylaxis is described as a serious, life-threatening systemic hypersensitivity reaction (1). As mentioned above, a patient who has anaphylaxis related findings and symptoms but no specific trigger is diagnosed with Idiopathic Anaphylaxis by ruling out the other causes in differential diagnosis (2-7). The patient is diagnosed with detailed history, physical examination, by ruling out the potential diseases and with proper laboratory tests. Test platforms such as ImmunoCAP ISAC 103 ve ImmunoCAP 250 tests which search a large number of allergen series and even in idiopathic cases, food proteins like omega- 5 gliadin and shrimp are determined as the factor (1).

In our patient, there was no reason to trigger anaphylaxis in skin and serum tests other than specific IgE positivity against Tomatoes. Since Turkish pizza can not be made without tomato and tomato paste, tomato allergy may explain the suspicious reaction after Turkish pizza, but besides the lack of a positivity for walnuts and peaches, the development of three more attacks, the cause of which is unknown, made us think that the case was idiopathic anaphylaxis.

Treatment is determined by the frequency of attacks of idiopathic anaphylaxis. Individuals with idiopathic anaphylaxis may also undergo anaphylaxis from physical, emotional, and infection-related causes (e.g., trauma, tooth extraction, exercise, stress, anxiety). Idiopathic anaphylaxis, despite previous different classifications, is divided into two main classes according to the incidence of attacks (5). If more than two attacks in the last two months or more than six attacks per year are observed, it is considered as a common attack, whereas if it does not meet one of these two conditions it is considered as a rare attack (2-7). Combined treatment may be required in cases of idiopathic anaphylaxis with frequent attacks. Prednisolone and an $\mathrm{H} 1$ antihistamine treatment are recommended for three months (3). In rare cases, prophylaxis is usually not necessary. In patients undergoing Steroid therapy, malignant idiopathic anaphylaxis should be considered when steroid therapy cannot be discontinued over time (8). In malignant idiopathic anaphylaxis, steroid therapy cannot be reduced or attacks are observed although steroid therapy is used. Rituximab and omalizumab (anti-IgE) therapy may be tried in these patients $(1,8)$. In our patient, sympathomimetic (albuterol) and triple (ketotifen + ranidine + montelukast) prophylactic treatment, which is indicated in the literature, was especially controlled without the need for systemic steroid use and medical care costs were reduced $(9,10)$.

Monitoring during the first months of irregular treatment; 2 attacks in a month observed in patients by changing $\mathrm{H} 1$ antihistamine drugs (pheniramine and cetirizine) antihistamines ketotifen and $\mathrm{H} 2$ (Ranitidine) and adding Montelukast. Frequency of the attacks decreased (4 attacks/15 months) and all the attacks completely were under control with this combined drug treatment. In the past 12 months the attacks had disappeared and the drugs were completely cut-off (Figure 1). Here we would like to emphasize the failure of first and second generation antihistamines in our patient and in particular that the combination of ketotifen + montelukast is beneficial. It has been reported that fatality is low in these patients, they are mostly in remission with drug treatment, and the prognosis is good.

In differential diagnosis; Idiopathic Anaphylaxis can be misdiagnosed with systemic diseases such as mastocytosis, malignancies, pheochromocytoma, carcinoid syndrome, autonomic epilepsy, hereditary and acquired angioedema (2-7). To rule out the mastocytosis disease, tryptase level was checked and found to be low. The other malignancies and epilepsy were not considered with the patient's clinic and laboratory findings. Considering the angioedema etiology; since the patient had urticaria during the attack and $4^{\text {th }}$ component (C4) of complement was normal, this results in ruling out the hereditary and acquired angioedema.

As a result, idiopathic anaphylaxis should be considered in patients with anaphylaxis symptoms whose cause is not fully determined even if different causes are suspected. By ruling out the differential diagnosis reasons, detailed anamnesis and tests will result in certain diagnosis of idiopathic anaphylaxis. Considering the probability of having attacks spontaneously (with no reason), the patient should be prescribed with epinephrine auto-injector appropriate for his/her age and warned to keep themselves away from physical, emotional disorders and infections.

\section{Ethics}

Informed Consent: An informed verbal consent was provided from the patient's parents for this report.

Peer-review: Internally peer-reviewed.

Financial Disclosure: The author declared that this study received no financial support.

\section{References}

1. Simons FE, Ebisawa M, Sanchez-Borges M, Thong BY, Worm M, Tanno LK, et al. 2015 update of the evidence base: World Allergy Organization anaphylaxis guidelines. World Allergy Organ J 2015; 8:32.

2. Nwaru BI, Dhami S, Sheikh A. Idiopathic Anaphylaxis. Curr Treat Options Allergy 2017; 4: 312-9.

3. Greenberger PA. Idiopathic anaphylaxis. Immunol Allergy Clin North Am 2007; 27: 273-93. 
4. Ditto AM, Harris KE, Krasnick J, Miller MA, Patterson R. Idiopathic anaphylaxis: a series of 335 cases. Ann Allergy Asthma Immunol. 1996; 77: 285-91.

5. Ditto AM, Krasnick J, Greenberger PA, Kelly KJ, McGrath K, Patterson R. Pediatric idiopathic anaphylaxis: experience with 22 patients. J Allergy Clin Immunol 1997; 100: 320-6.

6. Fenny N, Grammer LC. Idiopathic anaphylaxis. Immunol Allergy Clin North Am 2015; 35: 349-62.

7. Greenberger PA, Lieberman P. Idiopathic anaphylaxis. J Allergy Clin Immunol Pract 2014; 2: 243-50.
8. Özdemir Ö, Bozkurt HB, Elmas B. Omalizumab's role in the treatment of steroid dependent malignant idiopathic anaphylaxis. Turk Pediatri Ars 2017; 52: $105-7$.

9. Krasnick J, Patterson R, Harris KE. Idiopathic anaphylaxis: Iong-term followup, cost, and outlook. Allergy 1996; 51: 724-31.

10. Patterson R, Fitzsimons EJ, Choy AC, Harris KE. Malignant and corticosteroiddependent idiopathic anaphylaxis: successful responses to ketotifen. Ann Allergy Asthma Immunol 1997; 79: 138-44. 